\title{
BEST PRACTICES OF ASSESSMENT AS A WAY TO PROMOTE EFFECTIVE LEARNING
}

\author{
Dušica D. Rodić \\ University of Novi Sad, Republic of Serbia
}

The conceptual understanding presents a key component of science expertise, and thus the most desirable outcome of science education process. However, reports in the literature describe the opposite reality. There is an evidence that students are prone to use algorithms, to memorize rules, definitions and procedural steps, that is, to use efficient heuristics that allow them to skip logical reasoning for reaching an immediate goal (Dori \& Hameiri, 2003; Hammer, 1994; Nyachwaya, Warfa, Roehrig, \& Schneider, 2014). The questions arise:

(i) How the assessment tools themselves contribute to this phenomenon?

(ii) Can we encourage the development of logical reasoning among students by applying various assessment tools?

The viva voce assessment is probably the oldest type of knowledge examination. Due to its superior characteristics (development of communication skills, development of critical thinking, the possibility of diagnosing scientific reasoning or misconceptions, profound analysis of student knowledge etc.), this form of examination remained the traditional teaching practice for hundreds of years (Huxham, Campbell, \&Westwood, 2012). Yet, contemporary issues such as the continued expansion of the curricula at all levels of education, large lecture at tertiary level and many other objective reasons, have made written exams more widespread in the teaching practice. Unfortunately, this has made many students learning for tests, and many teachers teaching to the test, thus ultimately turning teaching practice into students' preparation to test well.

The simplest written exams, that were most frequently used, consisted of standard multiple-choice questions (Aronson \& Krause, 1982). This format is likely to be still in the wider use among teachers, despite some objective shortcomings such as the high possibility of guessing the correct answers, assessment of knowledge at the level of reproduction, lack of creative thinking etc. On the other hand, the academic community offers a wide range of novel approaches in the field of students' assessment, which are far less represented in teaching practice, but which seems to require the greater engagement of students, thus leading to the optimization of the learning process.

As the author of this Editorial, reflection on this topic from the perspective of personal research experience, seems appropriate. First, one should look at the multi-tier tests that were created from the real need to eliminate the shortcomings of the common multiple-choice questions. From the pioneering work of Treagust (1986), and later on in the fields of physics (Caleon \& Subramaniam, 2010; Chu, Treagust, \& Chandrasegaran, 2009), chemistry (Coştu, Ayas, Niaz, Ünal, \& Çalık, 2007, Milenković, Hrin, Segedinac, \& Horvat, 2016; Yan \& Subramaniam, 2018), astronomy (Kanli, 2014), biology (Arslan, Cigdemoglu, \& Moseley, 2012; Kılıç \& Sağlam, 2009), researchers have continuously reported on the benefits of applying two-tier, three-tier and four-tier tests. The basic advantage over common multiple-choice tests is reflected in the fact that multi-tier tests do not only examine the phenomenon but also probe the reasoning behind it, thus requiring greater involvement of students.

Further, in the context of the recently described forms of assessment, systemics should be mentioned as well. This form of assessment was introduced by Fahmy and Lagowski (2002) to promote meaningful learning. These authors presented systemic questions - closed, interacting conceptual systems, which require students to correlate the existing concepts and discover new relations among them. Further development of these tasks by different authors (Hrin, Fahmy, Segedinac, \& Milenković, 2016; Hrin, Milenković, \& Segedinac, 2018; Vachliotis, Salta, Vasiliou, 
ISSN 1648-3898/Print/

ISSN 2538-7138/Online/

\&Tzougraki, 2011), led to the creation of very effective tools that enable development of higher-order thinking skills. Integral parts of the curriculum of every physical science subject are problem solving tasks. However, the majority of problem-solving tasks encountered at primary, secondary and even tertiary level of education require lower-order cognitive skills to reach a solution. It means that such tasks can be solved successfully, using appropriate algorithms without proper conceptual understanding. To solve this problem, researchers (Overton \& Potter, 2008; Overton, Potter, \& Leng, 2013) have developed open-ended questions based on real-life context, correct solution of which is not unique, i.e. there is more than one acceptable answer. Such tasks require higher-order skills and are highly desirable in teaching practice.

The above-mentioned examples are just a few of the current forms of assessment that arose as a result of the science education research, while there are far more positive examples in the literature. Nonetheless, based on the previous, it is clear that good assessment practices play a significant role in fostering effective learning and therefore their application in teaching practice is extremely important. The prime question that arises here is how familiar the teachers are with these modern forms of assessment? In different countries, the situation varies but generally holds the opinion that teachers do not receive much formal training in assessment design within initial teacher training. For this reason, it often happens that teachers rely heavily on the assessment tools provided by textbook publishers or some other sources, which do not support students' learning. This certainly points to the need to modernize and adapt curricula of relevant courses within initial teacher education, regarding assessment design and analysis, but besides that, it points to the need for additional programs of continuing professional development that would encompass training in assessment.

Finally, some dilemmas remain to be considered:

(i) Do teachers really have a choice?

(ii) What will be the consequences for those who opt for good teaching practice instead of good scores on the test?

(iii) What can be done on this matter?

Either way, although we can have different views on the issue, the ultimate goal should be the same for all of us - students with knowledge beyond memorization and algorithms.

\section{References}

Aronson, J. N., \& Krause, E. C. (1982). An alternative type of objective exam. Journal of Chemical Education, 59 (5), 381-381.

Arslan, H. O., Cigdemoglu, C., \& Moseley, C. (2012). A three-tier diagnostic test to assess preservice teachers' misconceptions about global warming, greenhouse effect, ozone layer depletion, and acid rain. International Journal of Science Education, 34 (11), 1667-1686.

Caleon, I. S., \& Subramaniam, R. (2010). Development and application of a three-tier diagnostic test to assess secondary students' understanding of waves. International Journal of Science Education, 32 (7), 939-961.

Chu, H. E., Treagust, D. F., \& Chandrasegaran, A. L. (2009). A stratified study of students' understanding of basic optics concepts in different contexts using two-tier multiple-choice items. Research in Science \& Technological Education, 27 (3), 253-265.

Coştu, B., Ayas, A., Niaz, M., Ünal, S., \& Çalık, M. (2007). Facilitating conceptual change in students' understanding of boiling concept. Journal of Science Education and Technology, 16 (6), 524-536.

Dori, Y. J., \& Hameiri, M. (2003). Multidimensional analysis system for quantitative chemistry problems - symbol, macro, micro and process aspects. Journal of Research in Science Teaching, 40 (3), 278-302.

Fahmy, A. F. M., \& Lagowski, J. J. (2002). Systemic approach to teaching and learning chemistry: SATLC in Egypt. Chemical Education International, 3 (1), AN-1.

Hammer, D. (1994). Epistemological beliefs in introductory physics. Cognition and Instruction, 12 (2), 151-183.

Hrin, T. N., Fahmy, A. F. M., Segedinac, M. D., \& Milenković, D. D. (2016). Systemic synthesis questions [SSynQs] as tools to help students to build their cognitive structures in a systemic manner. Research in Science Education, 46 (4), 525-546.

Hrin, T., Milenković, D., \& Segedinac, M. (2018). Diagnosing the quality of high school students' and pre-service chemistry teachers' cognitive structures in organic chemistry by using student generated systemic synthesis questions. Chemistry Education Research and Practice, 19 (1), 305-318.

Huxham, M., Campbell, F., \& Westwood, J. (2012). Oral versus written assessments: A test of student performance and attitudes. Assessment \& Evaluation in Higher Education, 37 (1), 125-136.

Kanli, U. (2014). A study on identifying the misconceptions of pre-service and in-service teachers about basic astronomy concepts. EURASIA Journal of Mathematics, Science and Technology Education, 10 (5), 471-479.

Kılıç, D., \& Sağlam, H. (2009). Development of a two-tier diagnostic test to determine students' understanding of concepts in genetics. Eurasian Journal of Educational Research, 36, 227-244.

Milenković, D. D., Hrin, T. N., Segedinac, M. D., \& Horvat S. (2016), Development of a three-tier test as a valid diagnostic tool for identification of misconceptions related to carbohydrates. Journal of Chemical Education, 93 (9), 1514-1520. 
Nyachwaya, J. M., Warfa, A. M., Roehrig, G. H., \& Schneider, J. L. (2014). College chemistry students' use of memorized algorithms in chemical reactions. Chemistry Education Research and Practice, 15 (1), 81-93.

Overton, T., \& Potter, N. (2008). Solving open-ended problems, and the influence of cognitive factors on student success. Chemistry Education Research and Practice, 9 (1), 65-69.

Overton, T., Potter, N., \& Leng, C. (2013). A study of approaches to solving open-ended problems in chemistry. Chemistry Education Research and Practice, 14 (4), 468-475.

Treagust, D. (1986). Evaluating students' misconceptions by means of diagnostic multiple-choice items. Research in Science Education, 16 (1), 199-207.

Vachliotis, T., Salta, K., Vasiliou, P., \& Tzougraki, C. (2011). Exploring novel tools for assessing high school students' meaningful understanding of organic reactions. Journal of Chemical Education, 88 (3), 337-345.

Yan, Y. K., \& Subramaniam, R. (2018). Using a multi-tier diagnostic test to explore the nature of students' alternative conceptions on reaction kinetics. Chemistry Education Research and Practice, 19 (1), 213-226.

Received: August 25, 2018

Accepted: October 02, 2018

Dušica D. Rodić PhD, Assistant Professor, University of Novi Sad, Faculty of Sciences, Trg Dositeja Obradovića 3, 21000 Novi Sad, Serbia.

E-mail: dusica.milenkovic@dh.uns.ac.rs

Website: https://personal.pmf.uns.ac.rs/dusica.milenkovic 